function than conservative treatment. ${ }^{15}{ }^{16}$ Early tangential excision may also have the short term disadvantage of cyst formation beneath the skin grafts. ${ }^{20}$ Once the hands have healed elastic pressure gloves worn for many months should control hypertrophic scarring.

In the third group if there are many casualties patients with $20-30 \%$ body surface area burns may be managed with oral fluids alone $(4 \mathrm{~g}$ sodium chloride and $1.5 \mathrm{~g}$ sodium bicarbonate in 1 litre of water, made palatable with orange squash) and remain in the district general hospital..$^{2122}$ Sorensen found that $80 \%$ of patients with burns of $<45 \%$ of body surface area may be managed with salt tablets washed down with fluids. ${ }^{23}$ Ideally patients with $30-60 \%$ body surface area burns and otherwise fit should be managed in burn units or centres because of their needs for intensive fluid replacement, monitoring, and adequate numbers of trained nurses (four trained nurses per patient per 24 hours).

Patients in the fourth group have a probable high mortality, and decisions to transfer any of them should be made at the district general hospital by a senior clinician from the nearest burn unit as soon as feasible. Patients whose main lesion is lung damage- - existing or anticipated (it may take several days to be a clinical problem)-should have their carboxyhaemoglobin concentration measured, ${ }^{24}$ be given oxygen, and considered for intubation and ventilation if their lung function deteriorates. Associated injuries should be dealt with by appropriate specialties.

For all but the minor burns supportive treatment should consist of reassurance (often overlooked), intravenous analgesia if needed, intravenous fluids, and wound dressings, usually with silver sulphadiazine cream. The initial pain will subside considerably within four hours of injury, and giving unnecessary opiates should be avoided. The adequacy of intravenous fluid replacement should be judged by the clinical response (pulse and respiration rates and state of peripheral skin circulation), serial measurements of peripheral venous packed cell volume, and hourly measurement of urine volume $(1 \mathrm{ml} / \mathrm{kg} /$ hour for children, and over 30 $\mathrm{ml} /$ hour in adults). Many patients tolerate maintenance oral fluids well (adults up to 2 litres/day); any vomiting may be related to opiates. The most popular intravenous resuscitation regimen in Britain uses colloid as plasma protein fraction and the Muir and Barclay formula developed for use with freeze dried plasma, ${ }^{25}$ the likely colloid need for 24 hours being assessed as $2.5 \mathrm{ml}$ colloid $/ \mathrm{kg}$ body weight $/ 1 \%$ body surface area burn. This estimate is only a guide, and patients given plasma protein fraction seem to need greater volumes than those given freeze dried plasma. ${ }^{26}$ If there are many casualties supplies of colloid may run out, but an alternative crystalloid regimen is offered by the Parkland formula- 4 $\mathrm{ml} / \mathrm{kg}$ body weight $/ 1 \%$ body surface area burn $/ 24$ hours, with no oral fluids in the first 24 hours. ${ }^{27}$ All fluid needs should be calculated from the time of burning, and regardless of the regimen used frequent clinical assessments of the patient are essential.

In the face of mass burn casualties the extensive facilities and necessary manpower for the early excision of extensive burns are not likely to be available-but while early excision of deep dermal and full thickness burns reduces hospital stay and hastens return to work, ${ }^{28-30}$ it may not influence ultimate mortality. ${ }^{28}$

RICHARD W GRIFFITHS

Consultant Plastic Surgeon,

Fulwood Hospital

Sheffield S10 3TD
1 Faxon NW. Management of the Cocoanut Grove burns at the Massachusetts General Hospital. The problems of the hospital administration. Ann Surg 1943;117:803.

Wells DB. The circus disaster and the Hartford Hospital. N Engl f Med 1945;232:613-6.

2 Wells DB. The circus disaster and the Hartford Hospital. N Engl f Med 1945;23 3 Blocker V, Blocker TG. The Texas city disaster. Am J Surg 1949;78:756-71.

Blocker V, Blocker TG. The Texas city disaster. Am Y Surg 1949;78:756-71.

Enyart JL, Miller DW. Treatment of burns resulting from disaster. FAMA 1955;158:95-100. Schenk WG, Stephens JG, Burke J, Hale HW, Eagle JF, Stewart JD. Treatment of mass civilian burn casualties. Care of Cleveland Hill School fire victims. Arch Surg 1955;71:196-201.

6 Callahan JJ, Segraves JE. Treatment of fire victims: Lady of the Angel School disaster. Am 7 Surg 1960;99:814-6

7 Hart RJ, Lee JO, Boyles DJ, Batey NR. The Summerland disaster. Br Med J 1975;i:256-9.

8 Carswell JW, Rambo WA. A fire at Nakivubo, Kampala. 1. Management of the burned patients. Burns Incl Therm Inj 1976;2:178-83.

9 Allister C, Hamilton GM. Cardowan coal mine explosion: experience of a mass burns incident. $\mathrm{Br}$ Med f 1983;287:403-5.

10 Bull JP. Revised analysis of mortality due to burns. Lancet 1971;ii: 1133-4.

11 Slater RM, Hughes NC. A simplified method of treating burns of the hands. Br $\mathrm{f}$ Plast Surg 1971;24:296-300

12 Bailey BN, Desai SN. An approach to the treatment of hand burns. Injury 1973;4:335-40.

13 Sykes PJ, Bailey BN. Treatment of hand burns with occlusive bags: a comparison of 3 methods. Burns Incl Therm Inj 1976;2:162-8.

14 Frandsen PA, Overgaard-Neilsen H, Sommer J. Treatment of second-degree burns of the hand: a comparison of occlusive dressings and gloves. Burns Incl Therm Inj 1977;4:20-2

15 Salisbury RE, Wright P. Evaluation of early excision of dorsal burns of the hand. Plast Reconstr Surg 1982;69:670-5

16 Goodwin CW, Maguire MS, McManus WF, Pruitt BA. Prospective study of burn wound excision of the hands. F Trauma 1983:23:510-7.

17 Madden JW, Enna CD. The management of acute thermal injuries to the upper extremity. $f$ Hand Surg 1983;8:785-8.

18 Wang X-W, Sun Y-H, Zhang Z-M, Davies JWL. Tangential excision of eschar for deep burns of the hand: analysis of 156 patients collected over 10 vears. Burms Incl Therm Inj 1984:11:92-8.

9 Hunt JL, Sato RM. Early excision of full-thickness hand and digit burns: factors affecting morbiditv. F Trauma 1982;22:414-9.

20 Tandon $\mathrm{SN}$, Sutherland $\mathrm{AB}$. Some problems following tangential excision and skin grafting in dermal burns. Burns Incl Therm Inj 1977;3:96-9.

21 Phillips AW. Burn therapy: $\mathrm{V}$. Disaster management-to treat or not to treat? Who should receive intravenous fluids? Ann Surg 1968:168:986-96.

22 Artz CP, Moncrief JA. The treatment of hurts. 2nd ed. Philadelphia:W B Saunders Co, 1969.

3 Sorensen B. Management of hurns occurring as mass casualties after nuclear explosion. Burms Incl Therm Inj 1979;6:33-6

24 Clark CJ, Campbell D, Reid WH. Bloxd carboxyhaemoglobin and cyanide levels in fire survivors. Lancet $1981 ; 1: 1332-5$.

25 Muir IFK, Barclay TL. Burns and their treatment. London: Lloyd-Luke, 1962.

26 Watson JS, Walker CC, Sanders R. A comparison between dried plasma and plasma protein fraction in the resuscitation of burn patients. Burns Incl Therm Inj 1977;3:108-11.

Baxter CR, Shires GI'. Physiological response to crystalloid resuscitation of severe burns. Ann NY Acad Si 1968;150:874-94.

28 Curreri PW, Luterman A, Braun DW, Shires GT. Burn injury: analysis of survival and hospitalization time for 937 patients. Ann Surg 1980;192:472-8.

29 Gray DT, Pine RW, Harnar TJ, Marvin JA, Engrav LH, Heimbach DM. Early surgical excision versus conventional therapy in patients with 20 to 40 percent burns: a comparative study. $A m \mathcal{F}$ Surg 1982;144:76-80

30 Engrav LH, Heimbach DM, Reus JL, Harnar TL, Marvin JA. Early excision and grafting vs nonoperative treatment of burns of indeterminate depth: a randomized prospective study. 7 Trauma 1983;23:1001-4.

\section{The Debendox saga}

In 1956 a combined preparation of doxylamine, dicyclomine, and pyridoxine was marketed in the United States under the trade name Bendectin. It was widely used to treat nausea and vomiting early in pregnancy, and was marketed in Britain in 1958 as Debendox. Since that time, particularly in the United States, there have been anecdotal reports of women who had consumed Debendox (or Bendectin) and had later given birth to a malformed infant. Several studies, however, have failed to show any evidence of a connection between Debendox and congenital abnormalities. Nevertheless, the production of the drug was halted in 1983, and in the United States the manufacturers settled out of court the legal case in which claimants alleged that the drug had damaged infants in utero. Apparently to continue to defend the case would have cost more than the settlement. Probably 33 million pregnant women were exposed to Debendox. ${ }^{1}$ How was it that the scientific evidence was not conclusive?

When confronted by an infant with a congenital abnormality whose mother took Debendox in pregnancy, especially before the ninth week, the two events may easily be linked in the minds of the parents and others. Certainly this approach has been almost too appealing for many lay commentators. The scientific approach, however, should be very different, since most doctors (and many lay people) are

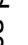

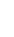

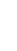

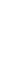

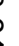
(1) 
aware that the spontaneous but variable incidence of birth defects unassociated with drug intake is between $2 \%$ and $7 \%$.

How can the uncertainties be resolved? One answer is to do a cohort study, in which women are identified whether or not they have been exposed to Debendox. The hope is that the women in the non-exposed group prove to be as nearly identical as possible with those in the exposed group. Many women need to be studied, often many thousands. Conventionally the results are expressed as a relative risk-that is, the incidence rate in the exposed group relative to the incidence rate in the non-exposed group. The standard error of the relative risk may also be determined, as may the $95 \%$ or $99 \%$ confidence limits.

Almost all the cohort studies performed have shown no increase in the relative risk of Debendox causing fetal malformations. ${ }^{1-11}$ Some of the trials have been criticised for lack of relevant controls, but in general they stand up well to criticism. Possibly some of the controls might have been exposed to Debendox inadvertently since it was available over the counter in Britain (and this caused problems for the defence in the first court action), but in fact it seems that very few women obtained Debendox in this way. ${ }^{12}$ An assessment of these studies combined gave a relative risk of 0.89 with $95 \%$ confidence limits of 0.76 and $1 \cdot 04 .^{13}$ Thus the data exclude a high grade teratogenic risk, but at conventional levels of probability $(p \leqslant 0.05)$ they do not exclude the drug being a low grade teratogen with a risk above background of $4-5 \%$. This is just the level of risk that the Debendox action groups are claiming. ${ }^{14}$

The second approach is the case-control investigation, in which women are identified whose infants have the defects under study (usually cleft lip, cleft palate, limb reduction deformities, and cardiovascular abnormalities) and a control group of women is chosen whose children do not have these defects. Often the control women considerably outnumber the test group. Information about prior exposure to Debendox is sought, and the odds ratio with its standard error can be determined. This type of study is sometimes considered more powerful than a cohort study, but it has problems, too, such as over the counter sales of the drug and recall bias. Clearly mothers whose infants are deformed will remember more accurately the drugs they took in pregnancy than those with normal children, particularly if the birth in question was several years earlier. Several case-control studies have been performed and in general they have found no association between Debendox and fetal abnormalities. ${ }^{15-18}$ A weak association was found, however, between congenital heart defects ${ }^{19}$ and oral clefts ${ }^{20}$ and Debendox. Elbourne and her colleagues have attempted to overcome some of the problems of the case-control studies ${ }^{21}$ and have repeated Golding's work. ${ }^{20}$ In studies in Cardiff and Aberdeen they found no evidence of an association between oral clefts and an exposure to Debendox.

What can we conclude from this saga? To leave the legal discussions aside, a meaningful public debate will not be possible on such topics as this until the public is better informed about biological matters. Debendox may be a low grade teratogen, but the case will almost certainly be impossible to prove either way in a scientific sense. Indeed, the identification of any low grade teratogen will always be very difficult. For both cohort and case-control studies many thousands of women need to be studied, with their controls carefully chosen. Even so, such studies will always be at the mercy of the well chosen anecdotal report.

What the public should be told is that we can never prove a drug to be $100 \%$ safe in man. Drug treatment should always be limited to those patients in whom its potential benefits outweigh the risks, and for nausea of pregnancy the equation will often be negative, since non-drug measures are often effective. ${ }^{1}$

\section{L'E ORME}

Professor of Clinical Pharmacology,

University of Liverpool

Liverpool L69 3BX

1 Anonymous. Debendox is not thalidomide [Editorial]. Lancet 1984;ii:205-6.

2 Langman MJS. Debendox in pregnancy. Many last words. In: Dukes MNG, ed. Side effects of drugs annual. No 6. Amsterdam: Excerpta Medica, 1982:316-7.

Bunde CA, Bowles DM. A technique for controlled survey of case records. Current Therapeutic Research 1963;5:245-8

4 General Practitioner Research Group. Drugs in pregnancy survey. Practitioner 1963;191:775-80. Milkovich L, Van den Berg B. An evaluation of the teratogenicity of certain antinauseant drugs. Am J Obstet Gynecol 1976;125:244-8.

6 Newman NM, Correy JF, Dudgeon GI. A survey of congenital abnormalities and drugs in a private practice. Aust NZ F Obstet Gynaecol 1977;17:156-9.

Smithells RW, Sheppard S. Teratogenicity testing in humans: a method demonstrating safety of Bendectin. Teratology 1978;17:31-5.

8 Fleming DM, Knox JDE, Crombie DL. Debendox in early pregnancy and fetal malformation. $B$ Med F 1981;283:99-101.

9 Jick H, Holmes LB, Hunter JR, Madsen S, Stergachis A. First trimester drug use and congenital disorders. FAMA 1981;246:343-6.

10 Harron DWG, Griffiths K, Shanks RG. Debendox and congenital malformations in Northern Ireland. Br Med F 1980;281:1379-81.

11 Gibson GT, Colley DP, McMichael AJ, Hartshorne JM. Congenital anomalies in relation to the use of doxylamine/dicyclomine and other antenatal factors. Med $\mathcal{F}$ Aust 1981;i:410-4.

2 Korcok M. The Bendectin debate. Can Med Assoc $\mathcal{J}$ 1989;123:922-8.

3 MacMahon B. More on Bendectin. FAMA 1981;246:371-2.

14 Hall JB. Debendox in pregnancy. Lancet $1981 ;$;ii: $154-5$

15 Nelson MN, Forfar JO. Associations between drugs administered during pregnancy and congenital abnormalities of the fetus. Br Med f $1971 ; \mathrm{i}: 523-7$.

16 Greenberg G, Inman WHW, Weatherall JAC, Aldelstein AM, Haskey JC. Maternal drug histories and congenital abnormalities. Br Med $\mathcal{~ 1 9 7 7 ; ~ i i : 8 5 3 - 6 . ~}$

17 Cordero JF, Oakley GP, Greenberg F, James LM. Is Bendectin a teratogen? fAMA 1981;245 2307-10.

18 Mitchell AA, Rosenberg L, Shapiro S, Slone D. Birth defects in relation to use of Bendectin in pregnancy. FAMA 1981;245:2311-4.

19 Rothman KJ, Fyler DC, Goldblatt A, Kreidberg MB. Exogenous hormones and other drug exposures of children with congenital heart disease. Am f Epidemiol 1979;109:433-9.

20 Golding J. Vivian S, Baldwin JA. Maternal anti-nauseants and clefts of lip and palate. Hum Toxico 1983;2:63-73.

21 Elbourne D, Mutch L, Dauncey M, Campbell H, Samphier M. Debendox revisted. Br f Obstet Gynaecol (in press)

\section{Families who care}

Relatives of patients with stroke and head injury are said to express anger and guilt and to tend to denial of their relative's illness-reactions which are familiar to doctors who treat these disorders. ${ }^{12}$ In both cases the illness has a behavioural as well as a physical component. Which is the more important in terms of the burden on relatives? What differentiates a normal coping strategy from a maladaptive one?

Emotional regression in patients with cerebral dysfunction may lead to their spouses feeling trapped and isolated and not having their own dependency needs met. ${ }^{3}$ The ability of the relatives to cope may be critical for patients' welfare. Isaacs argued that the strain on relatives of patients with dementia was often the trigger for admission. ${ }^{4}$ In a review of the psychological consequences of childhood leukaemia McGuire found that $20-30 \%$ of parents required psychiatric treatment (mainly for depression or anxiety), that $25 \%$ of mothers described chronic sexual difficulties, and that $20 \%$ of parents had serious marital disharmony. ${ }^{5}$ But are these figures atypical of adjustment in the community at large?

Among techniques used to rate the burden on relatives has been asking them to rate their own level of distress. One quarter of spouses of victims of myocardial infarction recorded moderate to high stress two months after the episode. ${ }^{6}$ Almost two thirds of the relatives of victims of 